\title{
Recuerdos de provincia: las bienales del Humor y la Historieta de Córdoba (1972-1979)
}

\section{Provincial Memories: The Córdoba Biennials of Humor and the Comic (1972-1979)}

Artículo recibido el I3 de febrero de 20I8; devuelto para revisión el 2I de agosto de 20I8; aceptado el 8 de marzo de 2019 .

Amadeo Gandolfo Universidad de Buenos Aires, Facultad de Ciencias Sociales, snark84@ gmail.com. http://orcid.org/oooo-0002-4600-9786

Líneas de investigación Historia del arte; historia cultural; estudios sobre historieta; sociología de la cultura.

Lines of research History of art; aesthetics; cultural history; comic-strip studies; sociology of culture.

Publicación más relevante "Entre el humor absurdo y la risa violenta: la revista Tía Vicenta y la más reciente dictadura militar argentina", Estudios Ibero-Americanos 44, núm. 2 (2018). DOI: I0.15448/1980-64X.20I8.2.27690

Pablo Turnes Universidad de Buenos Aires, Instituto de Investigaciones Gino Germani, Facultad de Ciencias Sociales, blopaturnes@gmail.com. https:// orcid.org/o0o0-0002-8163-1992.

Líneas de investigación Historia del arte; estética; historia cultural; estudios sobre historieta.

Lines of research Art History; aesthetics; cultural history; studies about comic-strips.

Publicación más relevante "La angustia y la palabra. H. P. Lovecraft según Alberto Breccia", en Oscar Steinberg, coord., Designis, núm. 22 (septiembre 20I5): III-I2O.

Resumen Entre 1972 y 1986 se realizaron seis Bienales del Humor y la Historieta en Córdoba, con sede en el Museo Municipal de Bellas Artes Genaro Pérez. Proponemos revisitar esos hechos culturales en el periodo 1972I979, signados por aspectos sociales y políticos complejos, al tener en cuenta que fueron clave para fundar un canon y una historización de la historieta y el humor gráfico argentinos. Los debates y tensiones entre la identidad regional, la nacional y la internacional; el arte, el oficio y el mercado; la gráfica y la iconología popular como elementos constitutivos de la argentinidad y la necesidad de inscribirse en una genealogía dominada por las potencias del norte: todos estos factores 
paradójicos estuvieron presentes y dejaron una importante marca en una construcción histórica que aún hoy seguimos discutiendo. Todo esto permite la revisión del pasado argentino reciente desde una perspectiva particular y poco frecuentada.

Palabras clave Historieta; humor gráfico; Argentina; arte y mercado; identidad nacional; exposiciones.

Abstract Between 1972 and 1986 six Biennial Conventions on Cartoons and Comics were held in the Municipal Museum of Fine Arts Genaro Pérez in the city of Córdoba, Argentina. Our aim is to revisit these cultural events, which took place during periods of social and political complexity, bearing in mind that they were key moments in the foundation of a canon and a historical account of cartoons and comic strips in Argentina. The debates and tensions between regional, national and international identity; art, work and market; graphics and popular iconology as constitutive elements of a notion of the "Argentine character", and the need to inscribe themselves in a genealogy dominated by First World countries. All these paradoxical factors were present and left an important mark in a historical construction that are still being debated today, all of which allows us to revisit Argentina's past from a particular and seldom frequented perspective.

Keywords Comic strips; cartoons; Argentina; art and market; national identity; exhibitions. 
DOI: http://dx.doi.org/10.22201/iie.18703062e.2019.115.2690

\author{
AMADEO GANDOLFO y PABLO TURNES \\ UNIVERSIDAD DE BUENOS AIRES
}

\title{
Recuerdos de provincia: las bienales del Humor y la Historieta de Córdoba (1972-1979)
}

\begin{abstract}
$\longrightarrow$ omencemos por la pregunta evidente: ¿por qué Córdoba y por qué el humor gráfico y la historieta en el Museo Municipal de Bellas Artes ne ha identificado tres características clave que se conjugaron en esas bienales llevadas a cabo entre 1972 y 1979: I) interdisciplinariedad (artes plásticas, diseño gráfico y dibujo); 2) popularidad; 3) una institución museística dispuesta a cobijar una relación más flexible entre artes menores y mayores. ${ }^{I}$

Si tenemos en cuenta lo postulado por Rugnone, podemos suponer, además, una serie de relaciones históricas concéntricas y de duración variable, las cuales se hicieron presentes de mawnera explícita en el discurso oficial de la Bienal, así como también en los debates y disputas entre diferentes publicaciones impresas involucradas en mayor o menor medida con los salones durante el periodo 1972-1979. ${ }^{2}$ Todo esto es posible sintetizarlo en tres puntos: en prin-
\end{abstract}

I. Andrea Rugnone, "Los salones inter(nacionales) de humor e historieta realizados en el Museo 'Genaro Pérez' (Córdoba) en 1972 y 1974”, I Congreso Internacional de Historietas Viñetas Serias, (Buenos Aires, 20IO); "La ra Bienal Internacional y 4a Bienal Argentina del Humor y la Historieta en el Museo Municipal de Bellas Artes “Dr. Genaro Pérez” (Córdoba, 1979)”, Afuera: Estudios de Crítica Cultural, año X, núm. I5 (diciembre de 2015).

2. Por cuestiones de limitación de espacio, además de ser una investigación en curso, nos hemos ceñido a la revista Hortensia, a los catálogos oficiales y a las citas a La voz del interior indicadas en los trabajos de Andrea Rugnone. Aún resta la tarea de relevar lo publicado al respecto en otros 
cipio, la manera en que las bienales sirvieron para cristalizar una idea de campo humorístico/historietístico, con su canon correspondiente, su entroncamiento con los ancestros europeos y estadounidenses, y las continuidades con el antecedente inmediato y local de la ra Bienal Mundial de la Historieta en el Di Tella (Buenos Aires) en 1968. ${ }^{3}$ Se retomaba así el conflicto descrito por la investigadora en ciencias sociales, Laura Vázquez, como "por un lado, la pretensión de que la historieta tuviera la tutela del arte y, por el otro, la defensa de los valores de la cultura de masas", 4 que provenía de los años sesenta.

Luego, está el modo en que este hecho tomó una posición interesante dentro de la disputa entre los dos centros urbanos más importantes de Argentina por apropiarse y convertirse en productores de "modernidad". En este caso, la competencia se dio claramente con Buenos Aires; en ese contexto, las bienales cordobesas se mostraron tanto como continuadoras, (re)apropiadoras y finalmente superadoras de tensiones que habían atravesado en la década anterior. También se puede enmarcar lo mencionado dentro de un proceso de larga duración en la disputa entre dos modelos de centralismo: el mediterráneo contra el atlántico-portuario. ${ }^{5}$

diarios porteños y publicaciones como Skorpio (publicada entre I974 y 1996), Humor (1978-1999) y Fierro (1984-1992).

3. La Primera Bienal Mundial de la Historieta, celebrada en el Instituto Di Tella en 1968, representó un importante mojón en la legitimación artística de la historieta argentina, en un momento en el que el mercado local se encontraba en el inicio de un largo proceso, que se extendería hasta la década de los noventa, de contracción y reducción. Organizada por Oscar Masotta y Enrique Lipszyc de la Escuela Panamericana de Arte, la muestra generó revuelo e interés en la historieta como objeto teórico y crítico, y también produjo resquemores entre los historietistas que no veían con buenos ojos la invasión del intelectualismo en lo que había sido una industria de masas. Esto también se debía a que el Instituto Di Tella (1959-1970) era considerado el centro de producción de arte de vanguardia contemporánea del país, con una idea internacionalista que lo asociaba a Nueva York y París. Los historietistas tendían a ser mucho más desconfiados y conservadores respecto a ese tipo de expresiones artísticas, puesto que, antes que nada, se veían a sí mismos como trabajadores de la industria del entretenimiento. Véase Laura Vázquez, El oficio de las viñetas. La industria de la historia argentina (Buenos Aires: Paidós, 2010).

4. Vázquez, El oficio de las viñetas, 108.

5. Desde el comienzo del proceso de ruptura con España a comienzos del siglo xix, Buenos Aires se presentó como el epicentro político de las antiguas provincias del virreinato del Río de la Plata. Por un lado, mantuvo su estatus de capital; por otro, su salida al Atlántico le permitió seguir comerciando y controlando la entrada y salida de los productos. La antigua capital virreinal estaba alejada del foco de los conflictos bélicos, y utilizó a su favor el empobrecimiento de los estados provinciales para convertirse en acreedora y reforzar así su control político de las mismas. 
Es notable que la primera bienal se realizara en 1972, en los estertores de la Revolución Argentina, una vez fracasado el proyecto de modernización desarrollista por vía autoritaria, poscordobazo, ${ }^{6}$ y a la caída del general Juan Carlos Onganía (1966-1970), 7 el cierre del Instituto Di Tella y la empresa automotriz Kaiser Argentina ${ }^{8}$ (representantes de la puja industrial/cultural de la década de los sesenta) y en plena radicalización política y armada. Era también previsible:

Por otro lado, Córdoba —ubicada en el centro del país— era una de las provincias más extensas y antiguas, contaba con la primera universidad del país fundada en I6I3 y era sede de poderes eclesiásticos, mercantiles, militares y políticos. Su enfrentamiento con Buenos Aires comenzó desde un inicio: en I8Io, Córdoba fungió como refugio de los grupos monárquicos que buscaban organizarse para retomar el control del virreinato que les había sido quitado por los criollos en Buenos Aires, movimiento que fue reprimido con éxito por la Junta porteña. De esta manera comenzaría una larga competencia entre las dos provincias por el liderazgo de los antiguos territorios con vistas a la unificación nacional. Si bien podríamos decir que la batalla fue ganada casi siempre por Buenos Aires, la competencia prosiguió en el siglo xx y aún se mantiene como constitutiva de las relaciones entre los dos polos políticos, culturales y económicos más importantes del país.

6. El cordobazo fue una gigantesca protesta social llevada adelante por obreros y estudiantes en la ciudad de Córdoba, en contra de la política de austeridad económica y de la interrupción de la democracia por parte del gobierno militar de Juan Carlos Onganía. Durante días, el centro de la ciudad se encontró en manos de los obreros y estudiantes, que lograron repeler a las fuerzas de seguridad. Este incidente marcó el primer choque en la larga marcha que culminaría con el fin de la "Revolución Argentina", el proyecto de modernización autoritaria que comandaba Onganía. Véase César Tcach, De la revolución libertadora al cordobazo: Córdoba, el rostro anticipado del país (Buenos Aires: Siglo XXI, 20I2).

7. Juan Carlos Onganía (I9I4-I995) fue un general del Ejército Argentino que asumió como presidente de facto en 1966, designado por una junta militar integrada por representantes de las tres fuerzas. La autodenominada Revolución Argentina (1966-1973) pretendía, manu militari, tomar el control en la dirección del proceso de desarrollo económico de corte industrial del país, en colaboración con capitales extranjeros. Para esto, suspendió el ejercicio de los derechos políticos ciudadanos hasta que pudiera considerarse que no serían una amenaza al plan del régimen. Sus medidas en el campo de la cultura en particular fueron sumamente represivas y reaccionarias, provocando un descontento que llevó a la radicalización política, a la naturalización de la violencia como herramienta de cambio y finalmente al desencanto con el régimen y la renuncia de Onganía a la presidencia en junio de 1970.

8. Kaiser Motors Corp. se instaló en Argentina en 1954 como parte de su política de ampliación de su mercado y dadas las ventajas ofrecidas por el gobierno de Juan D. Perón. En 1959, Industrias Kaiser Argentina (IKA) se alió con la empresa automotriz francesa Renault, la cual la absorbería definitivamente en 1975. La competencia con las plantas Ford y Chevrolet se amplificaba por la competencia Buenos Aires/Córdoba, no sólo en un nivel productivo y económico, sino también cultural: los salones IKA-Renault pretendían establecer un circuito de arte alternativo al de la capital porteńa. 
la apertura iniciada por el gobierno del general Alejandro Agustín Lanusse (19711973) — sucesor de Onganía— con vistas a la preparación de unas nuevas elecciones democráticas había iniciado un lento deshielo tanto político como cultural.

El inicio de la publicación de Hortensia en agosto de 1971, un año antes de la realización de la bienal, fue síntoma de esta revitalización. ${ }^{9}$ Dirigida por Alberto Cognini, la revista se presentaba con una identidad humorística marcadamente cordobesa, una combinación entre lo erudito y lo callejero, lo intelectual y lo chabacano. Como mencionaban Crist [Cristóbal Reynoso] y Roberto Fontanarrosa: "Cognini nos encargó reflejar ese humor ya existente en los bailes, en las canchas. Y, a pesar de que la revista es leída también por intelectuales, sabemos que esos cuenteros la usan como manual de consulta". ${ }^{\text {Io }}$

Así, hubo una serie de bienales que se mantuvieron durante el periodo 1972-1986, atravesando el núcleo duro y candente de la historia argentina contemporánea, ${ }^{\text {II }}$ desde una posición que se asumía como perdedora de una antigua batalla histórica, pero que, a su vez, era reivindicada desde una centralidad coyuntural. Es durante este lapso tan crítico cuando se formó el canon de la historieta argentina, entendiéndolo como un relato organizado, históricamente legitimado, con sus figuras reconocidas y la demarcación de límites con otros campos, medios y lenguajes.

Cabe entonces preguntarse cómo influyó ese decurso histórico en el momento de cristalización del campo de la gráfica masiva en Argentina; hasta qué punto el marco político-institucional dio impulso a una serie de discursos que confluían y disentían de manera simultánea respecto de cuestiones

9. La revista Hortensia sería publicada hasta 1989 , sobreviviendo en seis años a la muerte de su editor Alberto Cognini en 1983. Su periodicidad varió a lo largo de su historia: primero mensual, luego quincenal, finalmente retornaría a la periodicidad mensual.

IO. "Vida y pasión de Córdoba", Panorama, núm. 340 (22 de noviembre de 1973): 42.

II. Las bienales, como hemos mencionado más arriba, se iniciaron en el periodo de decadencia de la Revolución Argentina (1966-1973). A lo largo de su existencia se sucedieron el breve retorno de la democracia experimentado entre 1973 y 1976, que vio un primer gobierno de 20 días de Héctor Cámpora, delegado personal de Perón, y luego el tercer gobierno de Juan Domingo Perón, que duró hasta su muerte en julio de 1974. A partir de ese momento, el gobierno pasó a manos de su viuda, Isabel Martínez de Perón. La violencia política, ya presente debido a la tensión entre derecha e izquierda al interior del movimiento peronista y al accionar represivo de militares y fuerzas de seguridad, se incrementó durante su gobierno, que inició un rápido proceso de descomposición política y económica, culminando con el Golpe de Estado del 24 de marzo de 1976, el cual instauraría la dictadura cívico-militar más sangrienta de nuestro país: el Proceso de Reorganización Nacional (1976-1983). 
específicas del medio y, a su vez, cómo en esos debates particulares no dejaba de conjugarse la situación general del país y del mundo. En este trabajo analizaremos un primer periodo fundacional y celebratorio (1972-1974), y un segundo momento de reconocimiento, ampliación y complejización del proyecto curatorial (1976-1979).

\section{2-1974. La construcción de un canon}

Del ir al 30 de agosto de 1972, el Museo “Genaro Pérez” abrió sus puertas al público — que al parecer confluyó masivamente y de manera inédita para el número regular de visitantes anuales del museo-, en lo que sería la primera de una serie de bienales del humor y la historieta. ${ }^{12}$ El catálogo funciona como una suerte de mapeo de los actores sociales, políticos y económicos que convergieron en el salón: desde las autoridades civiles, comenzando por el intendente de facto de la ciudad de Córdoba, ingeniero Miguel Crucet (I97I1972), a los organizadores del evento (César Tomás Miranda, director del museo; el médico Antonio Salomón, director de la exposición; el dibujante y editor Alberto Cognini, como secretario general; y los colaboradores de Hortensia, Crist y Miguel Bravo Tedín, en el comité ejecutivo). También participaron la Universidad Nacional de Córdoba, las editoriales Abril, Columba y Rico Tipo, el Centro de Dibujantes de Córdoba, el Fondo Nacional de las Artes y la empresa IKA-Renault.

El diseñador del catálogo fue Miguel de Lorenzi, quien para la portada eligió una imagen probablemente basada en las fotografías de Harold Eugene Edgerton, donde una pluma utilizada como proyectil quebraba un foco de luz, dejando el momento del impacto congelado. ${ }^{13}$ Podemos sumarle la metáfora

I2. Según los datos recolectados por Rugnone, esta primera muestra habría contado con un número aproximado de 60000 visitantes en 20 días. Véase Rugnone, "Los salones inter(nacionales) de humor e historieta".

I3. Harold Eugene Edgerton (1903-1990) fue un fotógrafo e ingeniero eléctrico estadounidense quien en la década de los años veinte, en el MIT, desarrolló un tubo de flash que le permitió registrar imágenes con gran detalle. Esto permitió utilizar las luces estroboscópicas fuera del cuarto de revelado, convirtiéndolas en dispositivos portátiles integrados a las cámaras. Su trabajo también estuvo relacionado con el desarrollo del sonar y la fotografía en profundidades submarinas. Si bien sus experimentos tenían en principio un objetivo científico y técnico, las fotografías de Edgerton terminaron por ser apreciadas estéticamente. El Museum of Modern Art (MoMA) de Nueva York posee 29 placas fotográficas como parte de su acervo. 


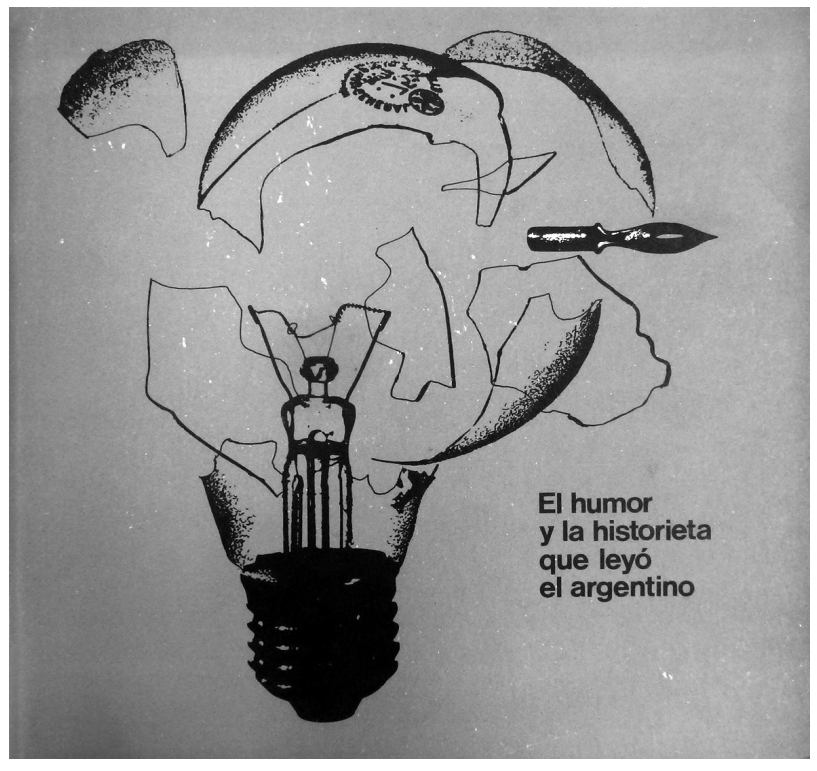

I. Miguel de Lorenzi, portada para el catálogo El humor y la historieta que leyó el argentino, 1972 , $21.5 \times 22 \mathrm{~cm}$, Córdoba. Archivo de Historieta y Humor Gráfico Argentinos, Biblioteca Nacional Argentina. (C) Archivo de Historieta y Humor Gráfico Argentinos.

visual de una lamparita (ícono clásico de la metáfora de "idea") siendo atravesada por una pluma, la cual supone la concreción material de aquello que se mantenía en abstracto. En síntesis, la labor del dibujante (fig. I).

También conviene señalar un lado más complejo respecto de la dimensión política de la metáfora visual de De Lorenzi. En 1972, las armas estaban cada vez más presentes en la vida pública y el ámbito político, además de su presencia constante en la publicidad y las notas en diferentes tipos de revistas. ${ }^{14}$ Está claro que se subrayaba el potencial punzante y siempre molesto del humor gráfico, pero dentro de ese contexto se nos presenta hoy, de manera perturbadora, otra capa simbólica acaso originalmente impensada, pero no por eso inocente.

Una segunda cuestión proviene del título dado a la exposición: "El humor y la historieta que leyó el argentino". Ahí ya hay una cuestión problemática: ¿quién es el argentino y qué sería eso que leyó? Lo que llama la atención en principio es el sujeto "el argentino". Se trataba de un sujeto menos definido que una franja etaria de la población y más cercano a la idea de la argentinidad y del ser nacional que habían sido objeto de debate durante la década de los

I4. Véase al respecto, el trabajo de Sebastián Carassai, Los años setenta de la gente común: la naturalización de la violencia (Buenos Aires: Siglo XXI, 20I3). 
sesenta por figuras de intervención pública tales como Jorge Abelardo Ramos, Juan José Hernández Arregui, Arturo Jauretche y Ricardo Carpani, entre otros.

Había ahí un uso ideológico complejo del término "argentino", definido desde el consumo de una serie de objetos que pertenecían a la esfera de los impresos periódicos, masivos y populares. El humor gráfico y las historietas habían formado en buena proporción la argentinidad de muchos argentinos. A su vez ¿qué revistas, periódicos, autores eran esos que habían contribuido con el proceso de reafirmación de una identidad nacional? Se trataba de producir un recorte y una selección que mostrara que detrás de los dibujos y los argumentos siempre hubo trabajadores de una industria, ahora elevados a la categoría de autores/artistas. La Bienal se proponía no solamente como una operación de difusión, sino también como una operación crítica.

Así, el hecho cultural recuperaba para sí ese papel de constructor de una tradición que estaba legitimada a priori por su permanencia en la memoria de los lectores y la cultura popular, y que ahora podía exhibirse en un museo público; la entrada masiva de los lectores y admiradores de personajes y caricaturistas al espacio museístico concretaba la solución a esa (falsa) escisión entre alta y baja cultura. ${ }^{\mathrm{IS}}$

Es interesante leer a la luz de esta perspectiva el texto introductorio de Enrique Luis Revol. El prólogo del intelectual cordobés es académico y erudito, colecciona una buena cantidad de fuentes citadas (del filósofo Henri Bergson, el historiador del arte Ernst Gombrich, el comunicólogo Marshall McLuhan, el antropólogo Bronisław Malinowski y el filólogo Károly Kerényi) y consiste en otorgarle a los cómics su base en la caricatura, que a su vez tiene su desarrollo histórico ligado a las artes. ${ }^{16}$ Se reforzaba la idea historicista y se le asignaba a Rodolphe Töpffer (I799-I846) la invención de la historieta moderna (algo excepcional dado que en ese momento se aceptaba canónica-

I5. Masotta de alguna manera lo había adelantado al afirmar: "Oculta en bibliotecas y archivos yace una extrańa subcultura, la historia de una relación escondida entre la cultura de masas y la política en la Argentina”, en Oscar Masotta, La historieta en el mundo moderno (Buenos Aires: Paidós, 1970), I43.

I6. Bart Beaty ha señalado el origen de esta operación, remontándose a la muestra del Louvre en 1967: "El espectáculo en el Louvre fue claramente un intento de rectificar esta situación demostrando que los artistas de tiras han recurrido a las reglas clásicas de la ilustración [...] el propio mundo del arte permaneció, en apariencia, sin convencerse.” Según el autor, en este intercambio desigual a la historieta le tocarían "las migajas de la mesa" del arte, véase Bart Beaty, Comics Versus Art (Toronto: University of Toronto Press, 2012), 194 (traducción del autor). 
mente al Yellow Kid de Richard F. Outcault como el fundador) ${ }^{17}$ Otra cuestión subrayada era la relación entre caricatura y política: siempre había sido un arma contra los tiranos. ${ }^{18}$

A su vez, en el discurso curatorial del director de la exposición, Antonio Salomón, explicaba que la muestra estaba organizada en torno a dos ejes: el humor gráfico y la historieta como dos medios y lenguajes, cada uno con sus propios códigos, tradiciones, intérpretes y maestros. Salomón afirmaba: "el hecho fundamental que nos decidió a realizar esta exposición no fue [...] sino mostrar al dibujante, al creador." '99 Esto era notable, dado que muchos de los dibujantes insertos en la genealogía de ambos medios no se habían considerado a sí mismos necesariamente "autores" sino, antes que nada, trabajadores de un oficio creativo e industrial a la vez.

Salomón establecía un parámetro que —a la manera del discurso del artebuscaba la originalidad por sobre la copia hacia el interior de un medio por definición pensado para ser reproducido más allá de sus originales (que solían no tener valor en sí, y que además solían ser propiedad de la empresa o del editor que los publicaba). Según esta perspectiva, el autor era el creador de la historieta, y no sus continuadores como era común en las tiras de prensa que duraban —e incluso duran hasta hoy - décadas, sobreviviendo a sus inventores.

Él representa una figura central en la organización de las bienales/salones desde su lugar de director de las mismas en sus seis ediciones. No es menor suponer que su figura y su posición curatorial en gran medida definieran el

17. Rodolphe Töpffer fue un pedagogo, escritor, pintor y caricaturista suizo, quien actualmente es aceptado como el fundador de la novela gráfica moderna. Entre I827 y I844 produjo ocho obras de tinte satírico-caricaturesco que incluían experimentos formales con los modos narrativos de la secuencia en cuadros y páginas. Richard Felton Outcault (I863-I928) fue un dibujante estadounidense quien comenzó su trabajo como profesional en el periódico de Joseph Pulitzer, el New York World, en I894. Al año siguiente, comenzaría la tira que lo haría famoso: Hogan’s Alley. En I896, Outcault pasó a trabajar para el competidor de Pulitzer, William Randolph Hearst, en el New York Journal. Por cuestiones legales, el nombre de la tira se llamó The Yellow Kid y fue publicada hasta 1898. Debido a que Outcault había utilizado por primera vez — en sentido moderno— los globos de diálogo (speech balloons) en esa serie, se consideró este recurso formal como la confirmación de que la historieta moderna había comenzado en Estados Unidos a finales del siglo XIX, algo que posteriores investigaciones discutirían reponiendo a Töppfer como fundador de la tradición historietística contemporánea.

18. Enrique Luis Revol, "Prólogo", en Antonio Salomón, ed., El humor y la historieta que leyó el argentino (Córdoba: Museo Municipal de Bellas Artes Genaro Pérez, 1972), 6-9.

19. Antonio Salomón, "Propósitos", en Salomón, ed., El humor y la historieta que leyó el argentino, IO. 
carácter de las bienales. Asimismo, participó durante estos años (1972-1979) en la revista Hortensia con diversas secciones periodísticas destinadas a la divulgación de la historia de la historieta argentina y mundial. Se justificaba la existencia de una de estas secciones, "El humor y la historieta de la A a la Z", "por la importancia que han adquirido todas las formas de comunicación mediante el diseño gráfico. Testimonio de esto es la preocupación de museos y universidades por mantener cursillos y realizar exposiciones que revisan la obra de los múltiples creadores". ${ }^{20}$

La inclusión de Salomón era una forma de complementar el trabajo de las bienales con un proyecto de divulgación. Al recurrir al interés de "museos y universidades", pretendía que las legitimaciones hermanas de lo popular y lo elitista, lo pedagógico y lo curatorial se encontrasen, algo que describía bastante bien el proyecto de Salomón al frente de las exposiciones.

Así, el catálogo de 1972 se dividía en tres partes: en caricatura el máximo referente era Oski (Oscar Conti), al que se le sumaba una línea que iba desde Diógenes Taborda y Alejandro Sirio a Guillermo Divito, Lino Palacios, Quino (Joaquín Salvador Lavado), Caloi (Carlos Loiseau), Copi (Raúl Damonte Botana), Fontanarrosa, Landrú (Juan Carlos Colombres), entre muchos otros. Lo mismo para la segunda parte, donde la figura seleccionada era Alberto Breccia, quien convivía con Hugo Pratt, José Luis Salinas, Arturo del Castillo y Héctor Oesterheld. Finalmente, se dedicaba un espacio a un recorrido histórico por las diferentes publicaciones nacionales.

En este punto encontramos ya un foco problemático que irá explicitando su contradicción a medida que se sucedan los salones: la necesidad, por un lado, de establecer una genealogía para cada medio afincado y legitimado por su pertenencia histórica a una identidad nacional (la argentina), recuperada y reivindicada desde otra local (la cordobesa); y, por otra parte, el inevitable reconocimiento a los antecesores europeos y estadounidenses como propietarios históricos de la inventio, en algún punto inigualables en ese mismo sentido de originalidad sobre el cual Salomón desarrollaba su discurso.

Tanto el recorte de la caricatura como el de la historieta promovían figuras nacionales como maestros (con Oski y A. Breccia como las variantes artísticas más experimentales). Sin embargo, no podían evitar desembocar en sus referentes estadounidenses como señalamiento de una historia comenzada en

20. Antonio Salomón, "El humor y la historieta de la A a la Z", Hortensia, núm. 56 (junio de 1974): 13. 
otra parte: el norte como potencia económica, génesis de la cultura de masas. Así, Saul Steinberg (19I4-1999) era el santo patrono de los caricaturistas, mientras que para los historietistas lo eran Milton Caniff, Alex Raymond, Bruce Hogarth, Chester Gould, Hal Foster y Roy Crane.

El concepto de "identidad argentina" se enrarecía, por otra parte, con la pertenencia disímil de nacionalidades entre los dibujantes (Breccia y Sábat eran uruguayos, Pratt, italiano, Del Castillo, chileno, Sirio, español, entre otros). A esto se le sumaba otro nivel, el institucional. La bienal cordobesa citaba como antecedentes al Louvre, el MoMA y el Di Tella, haciendo hincapié en la necesidad de extraer su uso social por parte de especialistas de diferentes ramas de la historieta (Oscar Steimberg, Oscar Masotta, citados e invitados). ${ }^{2 \mathrm{I}}$

La idea de Salomón consistía en un programa con tres objetivos: la creación de un museo específico de la historieta y el humor gráfico; una publicación regular que llevara adelante la lectura propuesta por la bienal; y la organización de más muestras. Lo primero no se cumpliría, lo segundo relativamente y lo tercero se concretaría en la forma de las bienales subsiguientes.

En la segunda Bienal (del 25 de octubre al is de noviembre de 1974), la exposición comenzó a tomar una forma más institucionalizada. Esto implicaba no sólo la repetición del elenco de figuras presentes dos años antes y la presencia de diferentes actores políticos y culturales, ${ }^{22}$ sino la consolidación del campo a partir de la instauración del Premio Sarrasqueta, ${ }^{23}$ esculpido por Alfio Caponchelli. Este gesto repetía el premio más célebre hasta ese momento, el Yellow Kid, otorgado en el festival italiano de Lucca. ${ }^{24}$ Los premiados fueron Alber-

2I. La muestra del Louvre titulada Bande Dessinée et Figuration Narrative (1967) se considera la primera muestra dedicada al cómic organizada por una institución ligada a las artes visuales clásicas. El MoMA era, por otra parte, el centro irradiador de modernidad en la segunda posguerra y en la segunda mitad de los sesenta sus exhibiciones de arte pop fueron fundamentales y causaron un gran alcance en parte de los artistas locales y en Masotta, en particular, quien viajó a Nueva York poco antes de organizar la Bienal en el Di Tella, en 1968.

22. Alberto Cognini había cedido su lugar como secretario a José Félix Feldmann y había pasado a conformar el comité de honor. Se habían sumado la editorial Atlántida y las revistas Satiricón, Skorpio y Mengano y el Instituto Goethe. Además, se había obtenido el reconocimiento de la Secretaría de Turismo de Carlos Paz. El catálogo fue editado por Siglo XXI Editores.

23. Don Goyo de Sarrasqueta es un personaje creado por el español Manuel Redondo, publicado en Caras y Caretas entre 1913 y 1928. Es considerada la primera serie argentina con regularidad, permanencia del mismo personaje y ambientación local. Se trataba de un inmigrante arribista que pretendía ascender en la escala social siendo a su vez despreciado y fracasando en sus intentos.

24. Evento impulsado por los italianos Romano Calisi y Rinaldo Traini en 1966 — profesores 
2. Miguel de Lorenzi, portada para el catálogo El humor y la historieta que leyó el argentino. Segunda muestra, 1974, $21.5 \times 22 \mathrm{~cm}$, Córdoba. Archivo de Historieta y Humor Gráfico Argentinos. Biblioteca Nacional Argentina. (C) Archivo de Historieta y Humor Gráfico Argentinos.

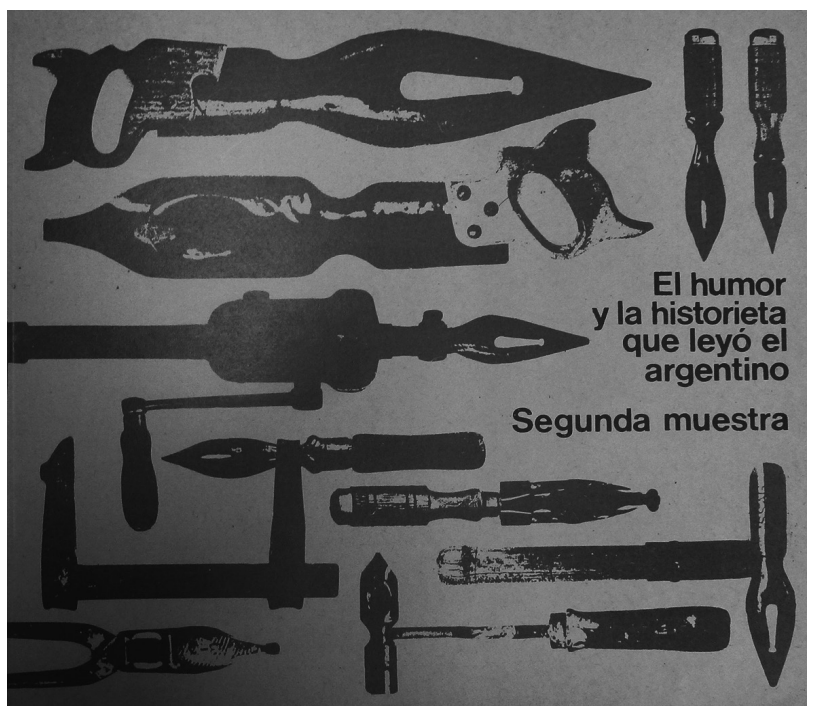

to Breccia, Lino Palacio, Oski y la revista Hortensia. Es decir, aquellos que ya aparecían como consagrados y comprometidos con el medio y el salón desde un principio.

La portada de la segunda muestra volvió a estar a cargo de Miguel de Lorenzi, quien sugería esta doble dimensión del artesanado industrial compuesto por humoristas e historietistas al desplegarse una especie de caja de herramientas que eran la fusión de los elementos de trabajo de un albañil o carpintero con las de un dibujante (fig. 2). Esta tensión constitutiva entre arte y mercado ${ }^{25}$ es una constante en la historia del campo historietístico. Guionistas y dibujantes suelen oscilar entre su estatus como trabajadores de una industria y autores

en la Facultad de Pedagogía en la Universidad de Roma, en la cátedra de Luigi Volpicelli-, con la idea de sostener un espacio de reconocimiento mutuo entre críticos, guionistas, dibujantes y otros participantes del mundo historietístico internacional. El resultado serían los salones de Lucca, donde se encontraban anualmente las diferentes generaciones y tradiciones de historietistas, y en el cual cada año le era otorgado a un autor el premio mayor: el Yellow Kid. La consagración que era a su vez la construcción simbólica de una línea que iba desde Richard Felton Outcault, como fundador de la historieta moderna, hasta sus herederos en el presente, en lo que constituía una operación de reconocimiento de la fundación estadounidense del lenguaje y sus refundaciones en general europeas, pero también sudamericanas.

25. Vázquez, El oficio de las viñetas. 
cuya producción es valorada estética y artísticamente. Sin embargo, el salto a las "artes mayores" ha estado por tradición obturado por las reglas del sistema cultural de Occidente, lo cual ha llevado a reforzar la idea de que los historietistas tienen de sí mismos: asalariados, especie de artesanado industrial, celosos y desconfiados de las instituciones tradicionales del arte y, al mismo tiempo, deseosos de obtener legitimidad más allá de los circuitos de la historieta.

Esta idea estaba reforzada por el prólogo de Salomón, en el cual reconocía el fracaso de la idea original de la Bienal, pero al mismo tiempo encontraba una victoria en la derrota, basando su argumento en la popularidad:

Muchos de los propósitos de la exposición anterior no se realizaron. No hubo conferencias, ni mesas redondas, ni actividad paralela considerable. Sin embargo, un solo hecho, fue de tan tremenda significación que por sí solo asegura el éxito de cualquier exposición: la asombrosa concurrencia de público a la muestra. Hubo personas que por primera vez iban al Museo [...] el saldo más positivo de ello fue el contacto entre el creador y su lector; la confortable comunicación entre el mensajero y el receptor. ${ }^{26}$

La imagen de un público provinciano entrando por primera vez a un museo - y el hecho de tener que ir a buscar a los personajes de las revistas populares a una institución semejante- era significativa en sí misma. Esto no escapaba al director, quien repetía enfáticamente la necesidad de crear un museo donde poder archivar y resguardar ese acervo de la memoria popular dado que el mismo estatus de "cosa baja" hacía peligrar su conservación.

El catálogo puede leerse, a la luz de estos propósitos, como una manera de mostrar y recomponer un orden histórico para todo ese material que se había ido acumulando sin ser reconocido. Las fotos de los autores se sucedían como un gran álbum familiar del humor y la historieta y, también, como una forma de darle imagen y cuerpo, presencia autoral corporizada en un rostro, a unas firmas a menudo fugaces. Éstos, a su vez, convivían con un glosario con personajes y publicaciones, ordenado alfabéticamente.

Apenas tres páginas fueron dedicadas al contexto internacional de ese desarrollo que ataba al siglo xIx con el xx. La línea de tiempo comenzaba en I829, cuando la publicación de la historieta caricaturística La vie de M. Vieux Bois de Rodolphe Töpffer atravesaba distintos países y sus creadores para llegar finalmente a los Estados Unidos donde se encontraba con la prensa moder-

26. Salomón, "Propósitos", 2. 
na, con dibujantes tales como James Swinnerton, Richard Felton Outcault, Rudolph Dirks, Winsor McCay, Frederick Burr Opper, historietistas pioneros del medio en los albores del siglo xx. La entrada de la Argentina a este esquema se producía en 1912 con Sarrasqueta (confundiéndola con la tira anterior de Redondo, Viruta y Chicharrón).

Hasta la década de los cincuenta, la casi totalidad de los ejemplos — amén de los argentinos - eran estadounidenses. El cambio se operaba en los sesenta cuando el eje volvía a Europa, comenzando por Francia (con Jean-Claude Forest y Guy Pellaert), siguiendo por Italia con Linus y Hugo Pratt, introduciendo algunos esporádicos casos argentinos: Mort Cinder de A. Breccia y Oesterheld ${ }^{27}$ y Mafalda de Quino ${ }^{28}$ (el primero había sido publicado Io ańos antes, y el segundo había dejado de publicarse en 1973). Estas obras argentinas eran las únicas que podían presentarse en ese contexto tanto desde la experimentación gráfica (en el caso de Mort Cinder) como desde el comentario político y la popularidad masiva (en el caso de Mafalda). Éste era el resultado de la crisis que la industria argentina había experimentado desde principios de la década de los sesenta y que para principio de los setenta parecía revertirse, aunque sin volver a experimentar la cantidad de ventas de las décadas previas (Rivera, 1992).

Mort Cinder apareció originalmente en la revista Misterix de la editorial Yago entre 1962 y 1964. La importancia de Mort Cinder se vuelve más significativa cuando consideramos su aparición en un periodo de crisis para la historieta argentina como lo fue gran parte de la década de los años sesenta, y el hecho de que para ambos autores representó la última gran obra que podrían encarar juntos.

27. Publicada en la revista Misterix de Editorial Yago entre 1962 y 1964. Esta revista había sido publicada desde 1948 por la Editorial Abril, hasta su venta a Yago en 1962 y finalmente con su cierre definitivo en 1965 . Se trataba de una revista de formato generalmente apaisado, que contenía varias historias - algunas autoconclusivas, otras continuadas, que iban desde la ciencia ficción a la aventura y el western. Mort Cinder tiene como personaje principal a un inmortal que cuenta a un anticuario - Ezra Winston- historias de sus vidas pasadas. Las historias alcanzan por momentos gran dramatismo, merced a la profundidad filosófica y humana de los guiones de Oesterheld y a la experimentación gráfica radical emprendida por Breccia, llena de claroscuros expresionistas y técnicas diversas e inéditas en la historieta. Es considerada una de las mejores obras de la historieta argentina y mundial.

28. Tira publicada entre 1964 y 1973 en Primera Plana, El Mundo y Siete Días Ilustrados respectivamente. A partir de 1966 comenzó a ser publicada en forma de álbumes compilatorios y hasta hoy sigue editándose de manera integral. Es probablemente la tira argentina de mayor éxito en la historia, al traducirse y publicarse en todo el mundo. 
Mafalda, por su parte, fue una tira publicada entre 1964 y 1973 en la revista Primera Plana (1964-1965), el diario El Mundo (1965-1967) y la revista Siete Días Ilustrados (1967-1973). La tira tuvo su origen como una campaña publicitaria encubierta para una línea de electrodomésticos de la empresa Siam-Di Tella, que nunca se llevó a cabo. Quino, su autor, inspirado por los Peanuts de Charles Schulz, rápidamente la convirtió en una tira de niños precoces quienes juegan y se divierten, pero también se comportan como adultos comentando las novedades políticas y económicas de Argentina y el mundo. Las tres publicaciones en las que apareció tenían como público a la clase media profesional en rápida vía de modernización de sus hábitos y costumbres, los intelectuales y los principales elementos políticos de Argentina. Si bien Primera Plana tiraba un promedio de 50000 ejemplares por número, se enorgullecía de que esos ejemplares llegaban a "grupos de poder" y que era leída por aquellos individuos con verdadera capacidad de decisión. ${ }^{29}$ El Mundo era un diario más tradicional, pero con gran penetración en la clase media y trabajadora. Siete Días Ilustrados era un magazine ilustrado inspirado en el modelo de Time y Life, el cual originalmente había llegado a Argentina en la forma de Primera Plana, más popular que esta última, aunque, su contenido se centraba también en la farándula local. Mafalda rápidamente se convirtió en una radiografía social de cierta clase media, de la cual presentó sus filias, fobias y posicionamientos políticos, culturales y económicos. A partir de 1966 comenzó a publicarse en forma de álbumes compilatorios y hasta hoy sigue editándose de manera integral. Es probablemente la tira argentina de mayor éxito en la historia, al traducirse y publicarse en todo el mundo. ${ }^{30}$

Sin embargo, lo interesante es cómo ante ese panorama algo yermo para la producción argentina — dentro de ese esquema dominado por Estados Unidos primero y Europa después - la misma Bienal se incorporaba a una serie de manifestaciones de las cuales ella misma sería su último avatar: la aparición del pop art, la fundación del Club de la Bande Dessinée y el socerlid (Société Civile d'Étude et de Recherche des Littératures Dessinées), ${ }^{3 \mathrm{I}}$ el Salón de Lucca, la exposición en el Louvre y la Bienal del Di Tella.

29. Elena T. Piñeiro, "Medios de comunicación y representación política: el caso de Primera Plana (1962-1966)", Temas de Historia Argentina y Americana I, núm. I (noviembre de 2002), 97-I32.

30. Para un trabajo de largo aliento acerca del contenido social e ideológico de Mafalda y sus apropiaciones políticas recomendamos el libro de Isabella Cosse, Mafalda: historia social y política (Buenos Aires: Fondo de Cultura Económica, 2014).

3I. Espacios de investigación y reflexión sobre la historieta como arte, con participación de varios 
En ese devenir, la Bienal cordobesa retomaba la lectura ditelliana - la idea de Argentina como punto de encuentro de las tradiciones estadounidense y europea- y la incorporaba a un proyecto que estaba tensionado, primero, por su pertenencia al mismo tiempo regionalista y nacional; y segundo, por la necesidad de anclarse mediante la construcción de una tradición argentina que no podía dejar de señalar a los maestros de Estados Unidos. De esta manera, la Bienal de Córdoba se proponía sintetizar y superar una situación doblemente periférica: ante las potencias imperiales y ante Buenos Aires. Para concretar el programa de las bienales debían seguirse las propuestas que Salomón apuntó en el prólogo "Propósitos", aunque dicho programa incurrió en ambigüedades debido a sus mismos proponentes más destacados. Por ejemplo, Alberto Cognini escribía en Hortensia acerca de las críticas que habían llegado durante el primer salón por su énfasis en las publicaciones y figuras porteñas: "El tema es interesante para señalar un fenómeno de localismo mal entendido que ignora la trascendencia nacional que tiene esta provincia. Parece que a Córdoba hubiera que amarla en el zaguán y con los ojos cerrados, y es tan fuerte ese cariño que la novia resulta más útil si no se la muestra para que no haya competidores." ${ }^{2}$

Es decir, que la preeminencia de Córdoba no implicaba la desaparición de Buenos Aires, sino su competencia saludable y también una aceptación realista de las limitaciones históricas de su industria cultural. Ahí era, entonces, donde lo popular y lo masivo volvían como el retorno de lo reprimido, la justificación final que servía como impulso al proyecto de Salomón y los autores (dibujantes y editores). Si la historieta ya no iba a la gente, entonces la gente debía ir a la historieta. Y en el proceso, desacralizar la institución museística abriéndola al público mediante aquello que había sido, por tradición, un no-arte.

De esta manera, se respondía en forma simultánea a los centros — Buenos Aires, París y Nueva York — ante los cuales Córdoba se presentaba periférica: la Bienal era una operación similar y evidentemente influenciada por esos acontecimientos anteriores. Por un lado, renegaba de cierto carácter elitista (el Louvre y el Di Tella como centros de la burguesía cosmopolita); por otro, retomaba

intelectuales académicos y artistas franceses. A la manera de los Cahiers du Cinéma, proponían crear un canon basado en la figura autoral de los historietistas, y una historia de la historieta mundial que privilegiaba fuertemente las creaciones estadounidenses como las obras fundacionales del cómic moderno. Prueba de esto fue la revista Cahiers de la Bande Dessinée (1969-1990).

32. Antonio Cognini, "Carta al que lee", Hortensia, núm. I8 (agosto de 1972): 3. 
lo mejor de esas experiencias (la institucionalización mediante la creación de espacios propios y la defensa de la historieta como un arte). ${ }^{33}$

Las bienales de Córdoba quedaron como esquirlas de aquellos combates por dirigir una modernidad periférica, dentro de un proceso de competencia entre capitales nacionales e internacionales. Una vez que esos actores se dispersaron (desde las vanguardias artísticas hasta las mismas industrias Di Tella y Kaiser), aquello que había quedado por fuera del arte experimental y vanguardista (o subsumido al pop) de pronto tenía una ventaja comparativa interesante: un goce estético de dimensiones plebeyas, la vida cotidiana y el arte encontrándose, aunque para eso hubiera que encumbrar a la historieta y, por tanto, resignificarla pagando el precio del recorte y la simplificación. Es decir, dejando de lado aquellas cosas del medio que no podían subsumirse a los circuitos del arte institucionalizado porque las historietas no habían sido producidas pensando en esos espacios, sino en un público masivo y desde dentro de una industria con sus propias reglas estéticas, ideológicas y comerciales —a menudo aplicadas y sostenidas férreamente.

$\mathrm{Al}$ aplicar una canonización a la manera de la historia del arte, se encontraba un sistema útil para la categorización y el ordenamiento cronológico, con la consecuente agrupación en escuelas y movimientos estéticos que la dejaban lista para ser fagocitada por el "gran arte". Sin embargo, no se podía evitar incorporar hacia el interior de las tradiciones historietísticas formas de pensar su propia historia que no le pertenecían, y a las que el medio tampoco pertenecía: la historia del arte había dejado tradicionalmente por fuera a las producciones culturales de ese tipo.

\section{6-1979. La historieta en la encrucijada}

La tercera Bienal llevada a cabo entre el is de noviembre y el 5 de diciembre de I976, vuelve inevitable que, por su propio contexto, se busquen pistas respecto

33. La historiadora del arte Andrea Giunta, hablando del mundo del arte, decía sobre los premios IKA: "en tanto Di Tella representaba magníficamente las aspiraciones de la burguesía nacional fortalecida en el marco del desarrollismo, Kaiser [...] estaba más ligada a las preocupaciones interamericanistas [...] [era] una iniciativa a contrapelo. Córdoba era un centro industrial y cultural importante, pero no podía competir con la capital del país. ¿Por qué esa necesidad de discutir la estructura de poder establecida? [...] más que promover un arte nuevo, procuraba crear un espacio cultural nuevo". Andrea Giunta, Vanguardia, internacionalismo y politica: arte argentino en los años sesenta (Buenos Aires: Siglo XXI, 2008), 199-200. 
a aquello que estaba sucediendo como resultado del terror y la represión sistematizada por el Proceso de Reorganización Nacional. La primera evidencia del avance de las fuerzas armadas sobre las instituciones se verifica en el listado de las autoridades políticas: la mayoría de ellas son militares, algunos retirados y otros en ejercicio. ${ }^{34}$

La breve introducción de Salomón es interesante si se la lee entre líneas: "Esta exposición logra, en este momento cumplir con la sentencia griega que se refiere a lo que ellos llamaban el alivio de lo cómico [...] no en función escéptica, ni frívola sino como realidad social”. Y se agregaba como remate, enfatizando: "No queremos conferir a estas muestras un carácter polémico, ni enciclopedista, sino testimonial". La idea de lo humorístico como catarsis, siendo a la vez válvula de escape y diversión políticamente no comprometida, hablaba de manera tácita del momento que se vivía, con la necesidad de no caer en dobles sentidos que podían ser malinterpretados por la autoridad. Incluso la portada de Di Lorenzi esta vez no parece ofrecerse a segundas lecturas contextuales: un bello y sencillo diseńo pop de un sacacorchos con alas de mariposa. La incongruencia visual sigue en la línea de las portadas anteriores, es decir, el señalamiento humorístico y virtuoso del trabajo (el sacacorchos que implica un esfuerzo) para llegar a la idea (las alas de mariposa que se elevan como resultado de ese esfuerzo). En síntesis, los dibujantes y guionistas como trabajadores representados por un símbolo popular como el artefacto que permite descorchar una botella de vino (fig. 3).

El catálogo se iniciaba con la imagen de un kiosco de revistas siendo visitado por lectores, con lo cual proponía una continuidad ante el quiebre institucional promovido por la dictadura: seguir leyendo historietas, ese lenguaje a la vez artístico y masivo, "propiamente argentino" como había sido establecido en el proyecto de bienales anteriores, frente a la violencia política. El prólogo de Norberto Firpo, por otro lado, parecía restablecer el costado más subversivo del humor sólo para neutralizarlo:

34. En esta ocasión, el catálogo había sido impreso con fondos de la Municipalidad de Córdoba, el diario Clarin y las editoriales Abril, Atlántida, Columba, Record y Hortensia. Esto se explicaba en parte porque se reproducían partes de entrevistas y notas publicadas en Clarín, Siete Días Ilustrado, Gente, La Opinión, entre otros. El resto de las entrevistas las hicieron el mismo Salomón y Carlos Trillo y Guillermo Saccomanno. Se le sumaban textos de Oscar Steimberg, Juan Parrotti, Carlos Marcucci, Kalondi, Alfredo Scutti, Mario Trejo y Luis Gregorich. 


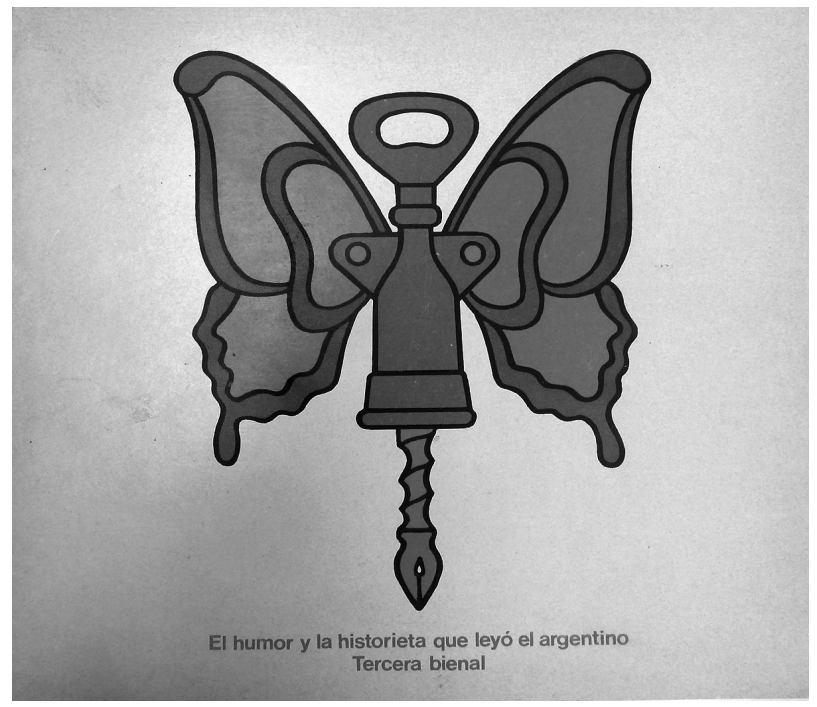

3. Miguel de Lorenzi, portada del catálogo $E l$ humor y la historieta que leyó el argentino. Tercera Bienal, 1976, Córdoba. Archivo de Historieta y Humor Gráfico Argentinos, Biblioteca Nacional Argentina. (C) Archivo de Historieta y Humor Gráfico Argentinos.

Los humoristas son fabricantes de espejos mágicos, pero ningún espejo mágico funciona hasta que un despistado se le planta enfrente y atina a sospechar que quizás ésa sea su verdadera imagen [...]. Quien hace reír, aunque talentoso, es un desertor de la realidad y por lo tanto un marginado de los reinos de este mundo [...] nuestra alegría interior — y no el autoabastecimiento de uranio— nos hará definitivamente hermanos. ${ }^{35}$

La ambivalente posición de Firpo — escrita en tono sarcástico, deliberadamente poco serio- hacía guiños a la posibilidad de reírse del régimen, pero no podía evitar terminar apelando a la "hermandad", sinónimo de la "unidad", términos muy presentes en el discurso dictatorial. ${ }^{36}$

35. Norberto Firpo, "No se detenga, esto es el prólogo", en Salomón, ed., El humor y la historieta que leyó el argentino. Tercera Bienal (Córdoba: Editorial Comercio y Justicia, 1976), 5.

36. En el mismo prólogo de Firpo también se incluye un par de párrafos de descarada misoginia: "El humor exige, pues, el esfuerzo de la elaboración intelectual, vicisitud que una lagartija no puede asumir. Y tampoco las mujeres, fíjense. Gracias a que las mujeres están más cerca de la lágrima que de la risa, pueden liberar — dicen los médicos — ciertos jugos que hacen falta para no incurrir en infartos (que representan, colijo, la vía más civilizada de muerte viril). El tema del por qué no hay mujeres humoristas — excepción hecha de las Madame Curie y las Golda Meier del género- merecería debatirse en algún próximo simposio internacional de feministas, si es 
Ésta es una buena síntesis de la duplicidad discursiva que atravesaba a toda la Bienal de 1976. Un ejemplo en concreto son los textos de Trillo y Saccomanno, que fueron intervenidos por el discurso curatorial para "corregir" un poco su posición, sin negarlos, pero asumiéndose como voz última y remarcar la calidad de invitados de los cronistas porteños. ${ }^{37}$

En ambos discursos se comprueban los informes sobre el estado del humor y la historieta hasta ese momento, los cuales poseen una serie de juicios estéticos sobre cierto sector de la producción, que intentan ser explicados o relativizados por la precariedad existente en el mercado de revistas. En el caso de Saccomanno, los factores de la crisis mencionados eran la diferencia monetaria entre la capacidad de pago de las industrias editoriales europeas y la argentina; la importación de revistas mexicanas a color y la televisión; todo esto dentro de una crisis generalizada del país, resultado de la suma de sucesivos quiebres políticos y económicos. El autor terminaba su texto con la siguiente reflexión:

La decadencia es fundamentalmente editorial. No hay que confundirla con decadencia de obras [...]. Hablar del fin de la historieta argentina es exagerado. Luego del éxodo de los grandes dibujantes de la Escuela Panamericana aparecieron nuevos valores. [...] la historieta argentina sigue manteniendo el mismo alto nivel de calidad de siempre, ese nivel que la consagró internacionalmente. ${ }^{38}$

que la programación de una nueva quema de corpiños no les ocupa todo el tiempo" (Firpo, "No se detenga, esto es el prólogo", 6). Patricia Breccia ha relatado cómo, en una de las bienales de los años ochenta, le escuchó decir a Crist (señalándola): "Esta mina dibuja bien porque dibuja como un tipo". Éste es un aspecto que sólo recientemente ha comenzado a discutirse con seriedad, y es cómo el canon de la historieta argentina, en sus recortes (que son operaciones ideológicas), ha dejado sistemáticamente invisibilizadas a las mujeres en la industria de la historieta, igualando autoría y talento a la dimensión masculina del dibujante. Sobre la cuestión de la masculinización de la tarea del dibujante, véase Beaty, Comics Versus Art.

37. Trillo y Saccomanno, además de sus guiones, escribían una columna en Skorpio y Tit-Bits (ambas publicaciones de Editorial Récord), donde publicaban notas y entrevistas con el objetivo que reclamaba Salomón desde 1972: especialistas críticos que recopilaran e indagaran en esa memoria colectiva poco sistematizada e historizada. Esos textos fueron finalmente compilados en el libro Historia de la historieta argentina (Buenos Aires: Ediciones Récord, 1980) que hasta el día de hoy se mantiene como una de las fuentes más importantes para el campo de estudios en el país.

38. Guillermo Saccomanno, "Los últimos tiempos de la historieta argentina 1968-1976", en Salomón, ed., El humor y la historieta que leyó el argentino. Tercera Bienal, I2. 
Así como Salomón encontraba una salvaguardia en la masividad del evento y la participación entusiasta de un público neófito en cuestiones artísticas, Saccomanno parecía hacerlo en la consagración internacional como manera de sostener cierta dignidad ante un panorama francamente desalentador. ${ }^{39}$ La paradoja estribaba, una vez más, en la contradicción entre el carácter internacional de una historieta nacional que parecía no poder superar el contexto de quiebre y decadencia que arrastraba desde 1960, y cuyos primeros síntomas de recuperación a partir de los años setenta habían sido echados por tierra ante la crisis político-económica a la cual no se podía nombrar, so pena de incurrir en acusaciones contra el régimen. Respecto a este punto de vista:

El Comité Organizador de esta Bienal quiere agregar que comparte, pero de distinta manera, el criterio de la llamada decadencia editorial; es necesario aclarar que considera que en la mayoría de los casos ella es debida a un desequilibrio económico [...]. En síntesis: decadencia editorial por desequilibrio económico y competencia internacional imposible de equilibrar debido a la fuerte demanda que tienen nuestros dibujantes en el extranjero. [...] Tampoco escapa a este Comité que la mayoría de los dibujantes ante la opción pesos por o dólares opten por lo segundo. ${ }^{40}$

En principio, la aclaración no pareciera tener sentido dado que prácticamente repite los argumentos de Saccomanno, dándole la razón. Sin embargo, puede entenderse como dos interpretaciones del mismo contexto desde diferentes perspectivas, sin salir del campo de la historieta. De esta manera, el Comité habla desde la posición de los editores, asumiendo un discurso en el que lo internacional aparece antes que nada como un factor amenazante y dañino —especie de "competencia desleal"—; mientras que en el discurso de un crítico aquello mismo aparece como la certificación de calidad estética de la producción local. No se culpa a los dibujantes que son — después de todotrabajadores, pero sobre todo artistas.

39. La posición "popular" aparecía explicitada en la entrevista realizada a Crist por Salomón: "en la exposición del Di Tella [...] se intelectualizó mucho la cosa y no alcanzó gran repercusión popular; en cambio en Córdoba sí, ya que han concurrido cien mil visitantes es decir un diez por ciento de la población de Córdoba”, Antonio Salomón, "Crist”, en Salomón, ed., El humor y la historieta que leyó el argentino. Tercera Bienal, 4I.

40. Guillermo Saccomanno, "Los últimos tiempos de la historieta argentina 1968-1976", en Salomón, ed., El humor y la historieta que leyó el argentino. Tercera Bienal, I2 
En esa distancia es donde se forjaban las diferencias: los editores apostaban a la masividad y apuntaban contra cierta "ambición" de los dibujantes, asumiendo un discurso patronal que se cubría con la defensa de la industria nacional —algo que ciertamente estaba siendo debatido de forma general debido a las políticas económicas del ministro José Alfredo Martínez de Hoz.

Saccomanno, a su vez, consideraba antes que nada la calidad de lo producido por sobre la cantidad, con el énfasis puesto sobre la historieta europea como modelo autoral y editorial a seguir. Justamente, ésta ha sido una de las acusaciones clásicas contra la historia propuesta por Trillo y Saccomanno: la oclusión y la minimización del papel de la editorial Columba en la historieta argentina. ${ }^{41}$ Lo cierto es que, si bien la mirada de los críticos ha remarcado la prioridad de la "estandarización" por sobre la de la calidad por parte de Columba, tampoco puede decirse que existiera un rechazo radical a este tipo de producción. En todo caso, se rescataban obras a pesar de haber sido generadas desde dentro de la maquinaria industrial y abaratadora de una editorial tradicional. ${ }^{42}$

La cuestión volvía a aparecer — algo patéticamente— en un recorte de dos páginas titulado “¿Existe la historieta nacional?”. La nota original había sido publicada en Clarín un ańo antes (el 28 de agosto de 1975), y desde ese interrogante se había convocado a una serie de dibujantes, editores y guionistas para dar su parecer. Ante semejante pregunta, Breccia y Saccomanno respondían que efectivamente existía, pero a la vez planteaban el debate acerca de qué era lo nacional. ¿Un espacio donde sucedían las aventuras, un determinado conjunto de géneros o tan sólo el lugar de origen de los autores? El ejemplo compartido era el de Sargento Kirk de Oesterheld y Hugo Pratt: allí donde se veía a un oficial del Séptimo de Caballería estadounidense, en realidad se escondía la épica gauchesca. ${ }^{43}$ Finalmente, ambos se apoyaban en el mismo argu-

4I. Columba fue la editorial que más tiempo permaneció activa de manera ininterrumpida en el mercado de la historieta: fundada en 1928, quebró definitivamente en 2001.

42. Tanto Trillo como Saccomanno trabajaban en Skorpio (Editorial Récord, 1974-1996) como guionistas, revista a la cual consideraban y proponían como continuadora del legado de Editorial Frontera de los hermanos Oesterheld, y lugar del nacimiento de la historieta argentina moderna y de autor. De ahí las suspicacias vertidas sobre las posiciones de los críticos.

43. La serie comenzó a publicarse en la revista Misterix de Editorial Abril en 1953 y luego se publicó entre 1957 y 196I en Frontera Extra y Hora Cero Suplemento Semanal de Editorial Frontera. Sargento Kirk contaba las aventuras y desventuras de un grupo de marginales y desertores, entre los que estaba un soldado del 7 mo de Caballería que no podía soportar la idea de exterminar a los indios. La idea original de Oesterheld era, al parecer, una historia situada en la frontera 
mento paradojal: la historieta nacional verificó su existencia al ser reconocida como escuela por los editores y el público europeo.

Por otro lado, el editor Alfredo Scutti y el dibujante Horacio Altuna sostenían que en parte la inexistencia de la historieta nacional se debía al contexto de 1976 , donde la competencia con los productos importados y los sueldos pagados en moneda extranjera habían obligado a abandonar el camino sostenido hasta 1960. En los dos casos se repetía un curioso argumento: la historieta argentina era aún demasiado joven, y no había terminado de "cortar el cordón umbilical" que la unía a sus antepasados estadounidenses y europeos - tal como aparecía en la genealogía propuesta por los catálogos de las bienales anteriores. Es interesante verificar cómo el papel de lo extranjero podía emplearse como una validación o un cuestionamiento. Vale considerar la frase final de Altuna:

Vemos aquí una gran tarea para los historietistas y editores argentinos: contar nuestras cosas y hacerlo a nuestra manera. Grandes zonas de nuestra cultura permanecen inexploradas por la historieta, que con sus alcances masivos les daría verdadera vigencia popular, fortaleciendo nuestra identidad e impidiendo así la penetración foránea. ${ }^{44}$

En el caso de Carlos Trillo, su informe sobre el estado del humor gráfico argentino era más escueto y sucinto con una cronología en la que se enumeraban las apariciones de diferentes publicaciones humorísticas y de quiénes habían participado en ellas..$^{45}$ Se mencionaban ciertos problemas legales sufridos por Satiricón entre 1974 y 1976, sin mencionar nombres ni mayores precisiones, lo cual era por demás entendible teniendo en cuenta el marco en el que se desarrollaba la Bienal. Satiricón, ${ }^{46}$ fundada en 1972 por Andrés Cascioli y

pampeana. Fue Cesare Civita, el editor y dueño de Editorial Abril, quien pidió que la acción se trasladara al far west.

44. “¿Existe una historieta nacional?”, en Salomón, ed., El humor y la historieta que leyó el argentino. Tercera Bienal, 20. Vale decir que, algo contradictoriamente con esta última afirmación, Altuna había trabajado a principios de los setenta para Gran Bretańa (donde la editorial Fleetway contrataba dibujantes argentinos desde 1960), y encontraría un gran éxito con obras como El último recreo (junto a Carlos Trillo) y Ficcionario, publicadas en Espańa a principios de la década de los ochenta.

45. Carlos Trillo, "Los últimos tiempos del humor argentino 1968-1976", en Salomón, ed., El humor y la historieta que leyó el argentino. Tercera Bienal, 46-49.

46. Satiricón fue una revista satírica publicada entre 1972 y 1976 en Buenos Aires. Lo mismo mezclaba la crítica a las figuras de la política y la farándula con un humor negro y corrosivo y altas 
Oskar y Carlos Blotta, había sido clausurada por el gobierno de Isabel Martínez de Perón, en septiembre de 1974. La clausura fue levantada — proceso judicial mediante- en junio de 1975 y la revista volvió a aparecer en diciembre de ese mismo año. En marzo de 1976 se publicó el último número, ya que ante las amenazas contra el personal editorial decidieron cerrar la empresa. ${ }^{47}$

Más interesantes eran las columnas dedicadas a Satiricón y Mengano "escritas por ellos mismos". La primera, sin firma, mencionaba que "Satiricón fue una revista de humor que nació en un momento de euforia, de apertura política. Era una época muy especial en la vida de los argentinos".${ }^{8}$ Mientras tanto, en el apartado dedicado a Mengano, ${ }^{49}$ Carlos Marcucci escribía que "cerró por una sola razón: la censura. Su último número fue secuestrado, y su tiraje fue bajando en forma directamente proporcional a los discursos de los ministros de economía y al apriete de la censura". so $^{\circ}$

El texto de Trillo, asimismo, era "corregido" por parte del Comité Organizador para incorporar revistas originadas y publicadas desde el interior. Nuevamente, el problema estaba dado por cierta omisión de aquello que afectaba en forma directa a los dos pilares ideológicos de las bienales: lo nacional y lo local. Sin duda, Trillo no había tenido la intención de ocultar esos casos; su reseña estaba centrada en aquellas publicaciones fundadas en general en Buenos Aires, las cuales ocupaban buena parte de su recorrido por cuestiones lógicas como

dosis de humor sexual. Su estilo desfachatado y abiertamente confrontativo representó un quiebre entre las revistas humorísticas argentinas, y esta distinción le valió un inmenso éxito, llegando a vender más de 200 ooo ejemplares mensuales. También le valió numerosos enfrentamientos con los gobiernos de Alejandro Lanusse, Juan Domingo Perón e Isabel Martínez de Perón, quien cerró la revista en septiembre de 1974.

47. Véase Mara Burkart, De Satiricón a HUM: risa, cultura y política en los años setenta (Buenos Aires: Miño y Dávila, 20I7).

48. "Satiricón por ellos mismos", en Salomón, ed., El humor y la historieta que leyó el argentino. Tercera Bienal, I6.

49. Revista dirigida por Carlos Marcucci y publicada entre 1974 y 1976. La revista contaba con la participación de varias figuras del humor gráfico que en varios casos habían publicado en Satiricón antes de su cierre forzado, tales como Alberto Bróccoli, Viuti (Roberto López), Roberto Fontanarrosa, Quino, Oski, Sanyú (Héctor Alberto Sanguiliano), Fati (Luis Scafati), Caloi, Serguei (Sergio Goizauskas), Lorenzo Amengual, Alberto Breccia, entre otros. Participaban también escritores y periodistas como Osvaldo Soriano, Jorge Halperín, Jorge Carnevale y Alejandro Dolina. Una sección no acreditada se llamaba "Naftalina. Algo del humor que leímos los argentinos", donde se reconstruía algo del corpus del humor gráfico nacional e internacional. Es posible que la sección estuviera a cargo de Bróccoli y Carlos Trillo.

50. "Mengano", en Salomón, ed., El humor y la historieta que leyó el argentino. Tercera Bienal, 45. 
público lector, poder adquisitivo, acceso a la infraestructura y a los capitales, circuitos de distribución, entre otros. El reproche del Comité revelaba la necesidad y el objetivo por parte de ciertos grupos del interior por ocupar una parte de esa cronología, en particular aquella que tomaba lugar en los últimos ańos.

Así, podemos sumar una postrera intervención de los críticos porteños que alcanza niveles simbólicos trágicos y profundos. Aparecida en el catálogo de 1976, la entrevista a Héctor Oesterheld sería la última antes de su secuestro por parte de un grupo de tareas en abril de $1977 .{ }^{\text {II }}$ Si bien la entrevista se ceñía al catálogo, se habían elegido las preguntas que trataban, en general, sobre el oficio de guionista y su posición frente y junto al dibujante..$^{52}$ Una pregunta final menciona La Guerra de los Antartes (dibujada por Gustavo Trigo), la cual se había publicado en el diario Noticias relacionada con Montoneros (donde militaba Oesterheld). 53

El diario había sido clausurado por el gobierno de María Estela Martínez de Perón en 1974, con lo cual la historieta no había llegado a su conclusión. Una síntesis posible de esta obra sería una especie de relato en tono de ciencia ficción de la utopía montonera, con los topoi clásicos de Oesterheld (la invasión alie-

5I. Los GT eran grupos parapoliciales y paramilitares especializados en ubicar, secuestrar y trasladar a los prisioneros (calificados genéricamente como subversivos) a los centros de detención clandestinos donde se los torturaba sistemáticamente, para luego decidir su destino, el cual solía ser la muerte. Estos grupos estuvieron activos entre 1974 y 1983 como brazos ejecutores del terrorismo estatal.

52. La versión extendida se publicaría en Historia de la historieta argentina cuatro años después, aunque intervenida por el editor Alfredo Scutti para suprimir las partes donde se hablaba de la política y la revolución. La entrevista completa se conocería en 2005 , a 30 años de haberse realizado, publicada por el colectivo rosarino La Bañadera del Cómic en el volumen Oesterheld en primera persona (Buenos Aires: La Bañadera del Cómic, 2005).

53. Montoneros fue una organización guerrillera activa entre 1970 y 1980. Se autodefinían como peronistas, y planteaban llevar al peronismo al nivel de vanguardia revolucionaria. Su perspectiva ideológica estaba compuesta por una serie de posiciones populistas, antiimperialistas y el catolicismo tercermundista. Su salida a la arena pública fue en 1970 con el secuestro y ejecución del general Pedro Eugenio Aramburu, antiguo presidente de facto de la llamada Revolución Libertadora que diera el golpe contra el gobierno de Juan Domingo Perón en 1955. En La Guerra de los Antartes, Oesterheld ponía en clave de ciencia ficción utópica una metáfora antiimperialista y una defensa del ideario montonero como proyecto refundacional de la política y la sociedad argentinas. El diario Noticias fue clausurado en 1974, a menos de un año de su aparición, por el gobierno de María Estela Martínez de Perón. Para recomponer su universo discursivo e ideológico recomendamos el libro de Daniela Slipak, Las revistas montoneras. Cómo la organización construyó su identidad a través de sus publicaciones (Buenos Aires: Siglo XXI, 20I5). 
nígena, el sacrificio heroico, la resistencia popular contra los grandes poderes aliados, entre otros). Los entrevistadores hacían hincapié directamente sobre la cuestión ideológica y Oesterheld contestaba que "hacia el final había una alegoría que servía no ya para Latinoamérica sino para el mundo entero, el proyecto tenía un final grandioso. No les cuento porque algún día voy a escribirlo" ${ }^{54}$

Ese final ahora se nos presenta desgarrador; una alegoría no voluntaria de un proyecto revolucionario fallido y derrotado ya a esa altura, prometiendo tener una continuidad que, huelga decirlo, nunca tuvo. Su final abierto, como el destino del guionista y tantos otros, no podía sino presentarse como un serio interrogante acerca de cuánto humor podía hacerse en medio de la masacre.

Por último, la Bienal de 1979, de carácter internacional, representó la apuesta máxima de estos encuentros, a la vez que el acallamiento de cierto proyecto fundacional. Realizada entre el 25 de mayo y el i7 de junio contó, por primera vez, con invitados internacionales de primer nivel: Moebius (Jean Giraud), Joe Kubert, Sergio Toppi, Dino Battaglia, Hugo Pratt, Claude Moliterni, Ralph Steadman. Un combinado que resumía lo mejor de la historieta de aventuras europeo-argentinas, los nuevos aires autorales franceses e inclusive lo más reconocido del establishment estadounidense. A estos nombres se agregaban los de algunos argentinos que se encontraban "triunfando en Europa": Guillermo Mordillo, Oski y Quino. El primero había realizado la mayoría de su carrera allí, pero Oski y Quino se encontraban exiliados, escapando de la dictadura militar iniciada en 1976.

El catálogo de la Bienal contaba en esta ocasión con apoyos para su edición provenientes de los diarios Clarín, La Prensa, La Razón, La Voz del Interior, Córdoba y Tiempo de Córdoba, pero, significativamente, sin la contribución de editoriales de historieta (la edición corrió a cargo de la municipalidad). Contaba con casi 200 páginas de textos e ilustraciones, organizadas por región geográfica y estilo (respetando la división humor gráfico/historieta) y con parte de sus textos traducidos al inglés para lectura de los visitantes internacionales. La portada, como de costumbre, era un diseño de Di Lorenzi que de nuevo no parecía proponer ninguna segunda lectura más allá de la metáfora de la imagen y el texto (el lápiz y la pluma) enroscándose una con otra, a manera de conciliación entre las dos unidades irreductibles que conforman la historieta.

54. Guillermo Saccomanno y Carlos Trillo, "Entrevista a Héctor Oesterheld”, en Salomón, ed., El humor y la historieta que leyó el argentino. Tercera Bienal, 35. 
La estructura y el contenido del mismo recordaba al catálogo de la ia. Bienal Mundial de la Historieta del Di Tella, continuando el diálogo plagado de enfrentamientos que los eventos cordobeses sostenían con ella. La colección de textos presente en sus páginas consagraba la compleja operación crítica de rescate, análisis y ordenamiento del canon que se había iniciado en 1972. En el mismo convivían textos de Carlos Trillo y Guillermo Saccomanno, Oscar Steimberg y Jorge $\mathrm{B}$. Rivera, convirtiéndose en un resumen de perspectivas históricas y del naciente campo de los estudios de la comunicación sobre la historieta argentina.

Además, aparecía el espectro de Oscar Masotta, en ese momento exiliado en Barcelona a causa de la dictadura militar y próximo a su muerte. Éste se presentaba en el catálogo mediante el texto que aporta el crítico y curador Jorge Glusberg - personaje siniestro y ambiguo del arte argentino durante la dictadura de 1976-1983 - titulado "La historieta y el arte", el cual consistía en un refrito de las ideas de Masotta, en ocasiones con frases idénticas a otras aparecidas en artículos una década antes. La propuesta de Glusberg partía de la noción de que la historieta era:

el medio donde el canal queda al descubierto, donde el espesor significante de los recursos a disposición del autor se trasluce en todos los casos [...]. Este aspecto es altamente significativo en relación con el arte actual. Sabemos que la obra denuncia sus condiciones de producción; la historieta, como género, satisface este requisito: en ella, todos los procesos de elaboración quedan inmediatamente a la vista. ${ }^{55}$

El punto de vista de Masotta había sido análogo a éste. Diez años antes escribía que la historieta "en su superficie misma revela, y pone de manifiesto, la existencia de un grupo de categorías de opuestos" ${ }^{56} \mathrm{Y}$, de igual forma, "esos signos exhiben en sí mismos la evidencia del 'lado palpable' que los constituye". 57 Glusberg se hace eco de esos puntos de vista masottianos para proponer una renovación del arte contemporáneo por medio de la historieta que pusiera al descubierto sus condiciones de producción y, también, por su carácter popular, por el "entrenamiento" al que la historieta somete al lector en la lectura de

55. Jorge Glusberg, "La historieta y el arte", en Salomón, ed., Primera Bienal Internacional y Cuarta Bienal Argentina de Humor e Historieta (Córdoba: Municipalidad de Córdoba, 1979), 8.

56. Oscar Masotta, "El 'esquematismo' contemporáneo y la historieta”, en Conciencia y estructura (Buenos Aires: Eterna Cadencia Editora, 20Io), 268.

57. Oscar Masotta, "Reflexiones pre-semiológicas sobre la historieta: el 'esquematismo"”, en Masotta, Conciencia y estructura, 3IO. 
los códigos constitutivos de su estructura, aspirara a una masividad inusitada: "de eso se trata: no de tematizar algo sino de ofrecer las reglas de un juego del cual el receptor puede participar activamente, jugando a su turno". 58

La culminación de la operación crítica propuesta por las bienales también se comprobaba en el primer texto de este catálogo, un artículo de Alberto Cognini titulado "El comienzo de estas bienales" en el que tematizaba su propia historia y proponía como balance positivo de estos encuentros el incremento del público, el contacto directo entre autores y lectores y, sobre todo, "la ineluctable presencia de un género con perfiles muy precisos en el campo de la comunicación y el arte. La historieta buscaba su aceptación semántica y también en Córdoba la reafirmó". 59

Había una prolongación, pero también un ligero reajuste de los propósitos del proyecto. Todavía era destacable el encumbramiento y conocimiento de los autores, la ampliación del público, pero ahora se destacaba la legitimación por medio del arte y la definición, cuasi académica, de un campo con sus códigos. Estas discusiones justificaban la realización de la Bienal, más que por un llamamiento nostálgico a la "historieta que leyó el argentino", por los grandes nombres internacionales y por la excepción, lo extraordinario y lo sobresaliente del campo.

En ese sentido también puede leerse la presencia del pintor Antonio Berni (1905-198I) como invitado de honor en la Bienal de 1976. El artista estaba embarcado en el último periodo de su carrera en el cual retornaba a las iconografías religiosas y de sacrificio como una forma de comentar la realidad de la Argentina dictatorial —a la vez que participaba de muestras y grandes actividades artísticas organizadas por el régimen. La presencia de Berni parecía apuntar a una doble legitimación: frente al mundo del arte contemporáneo y frente a lo que la autoridad estatal consideraba aceptable de ese campo. ${ }^{60}$

58. Glusberg, "La historieta y el arte" en Salomón, ed., Primera Bienal Internacional y Cuarta Bienal Argentina de Humor e Historieta, 9. Lo cierto es que Glusberg ya había escrito algo similar en su libro Retórica del arte latinoamericano (Buenos Aires: Nueva Visión, 1978), publicado un año antes, en el capítulo titulado "Las historietas y el arte latinoamericano". Para comprender mejor este tipo de estrategias discursivas y los cambios de posición de Glusberg dependiendo del contexto, véase Viviana Usubiaga, Imágenes inestables: artes visuales, dictadura y democracia en Buenos Aires (Buenos Aires: Edhasa, 2012).

59. Alberto Cognini, "El comienzo de estas bienales", en Salomón, ed., Primera Bienal Internacional y Cuarta Bienal Argentina de Humor e Historieta, 6.

6o. Para la compleja y ambigua posición de Berni durante la última dictadura, véase Usubiaga, Imágenes inestables. 


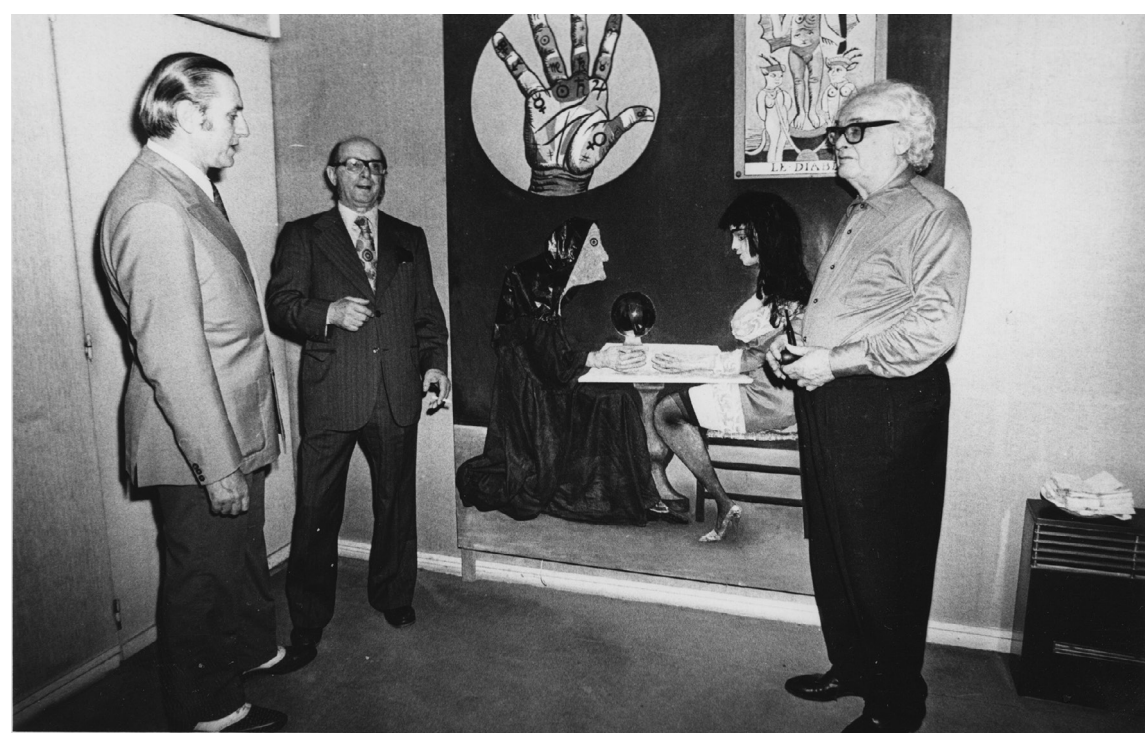

4. Antonio Berni posa enfrente de su cuadro Ramona y la adivina durante el transcurso de El Humor y la Historieta que Leyó el Argentino, Tercera Bienal, Córdoba, 1976. Archivo de Historieta y Humor Gráfico Argentinos, Biblioteca Nacional Argentina. (C) Archivo de Historieta y Humor Gráfico Argentinos.

Sin embargo, Berni ya había participado en la Bienal en una ocasión anterior. En 1974, uno de los almuerzos de la Segunda Bienal se había celebrado en el Complejo Aerosilla de Carlos Paz, ocasión en la cual se había apersonado Berni para terminar "haciéndole dibujitos a los presentes como lo hacían por ejemplo Quino, o Sergio Garaycochea, o Breccia, o Lino Palacio". ${ }^{6 r}$ Se destacaba la "presencia de lujo" de Berni, pero también se resaltaba que se "arremangó" para dibujar al igual que lo hacía un artista de historieta.

Las series de Juanito Laguna y Ramona Montiel realizadas por Berni construían un relato de vida mediante grandes cuadros de un niño y una niña de provincias que emigraban a la ciudad. Allí, Juanito se convertía en proletario explotado y Ramona en prostituta. Berni experimentó con diferentes técnicas, donde resaltan el collage utilizando desperdicios muchas veces encontrados en los basureros (incluyendo revistas de historieta). 
Gérald Gassiot-Talabot, crítico de arte francés citado por Masotta por acuñar el término figuración narrativa (figuration narrative), había definido las series de Juanito Laguna y Ramona Montiel presentadas en la muestra Mythologies Quotidienes en el Museo de Arte Moderno de París en I964 como "historietas plásticas". ${ }^{62}$ En ese anudamiento, en la cercanía de Berni al arte pop, su afecto por las formas artísticas populares y su utilización de personajes recurrentes en series, puede encontrarse el motivo que lo ubica como voz autorizada para legitimar el mundo de la historieta (fig. 4).

Esa nueva perspectiva se comprueba también en la posición que adopta esta edición de la Bienal frente al debate argentino/extranjero. Como hemos mencionado, su condición internacional deviene consagración última del proyecto. Los artistas extranjeros invitados eran presentados como "los grandes maestros internacionales" en las publicidades que le dedicaba la revista Hortensia. Sin embargo, ése era el mismo rótulo que se empleaba para describir a Mordillo, Quino o Sábat.

En la pugna entre una justificación por el arraigo popular en su país de origen y la consagración internacional, la balanza pareciera haberse inclinado hacia la segunda. Incluso a la hora de realizar un balance del hecho, se recurría a las palabras de Moebius, quien destacaba "la notable y abundante producción que existe en un país de tan baja demografía como es Argentina". ${ }^{63}$

Es igualmente destacable que la Bienal se realizara en Córdoba. Uno de los anuncios publicados en Hortensia subrayaba que "será otra muestra de la condición internacional que adquirió Córdoba; y que, de ahora en más, esta ciudad [...] impondrá su identidad continental sin complejos geográficos — Una de las ciudades del interior argentino con excepcional perfil". ${ }^{64}$ En otras palabras, la disputa entre Córdoba y Buenos Aires se resolvía por la definitiva validación internacional de Córdoba, confirmada en el carácter extraordinario de esta Bienal. Al superar a Buenos Aires, Córdoba se volvía ciudad continental.

62. Marcelo Pacheco et al., Antonio Berni: Juanito y Ramona (Buenos Aires: MALBA-Fundación Constantini, 20I4), 92.

63. Hortensia, núm. I24 (junio de 1979): 3.

64. Hortensia, núm. I23 (mayo de 1979): 28, en mayúsculas en el original. 


\section{Conclusiones}

La Bienal cordobesa logró afianzarse en los duros años de las dictaduras argentinas de la década de los años setenta como el espacio de organización del campo de la narrativa gráfica en Argentina. Esta idea de Córdoba como refugio de grupos de autores venidos de todas partes del país en momentos de gran violencia e inestabilidad política condujo a una serie de intervenciones que no conviene subestimar a la hora de entender cómo se organizó ese campo específico dentro de lo que llamamos, a grandes rasgos, la cultura nacional.

Desde el Museo "Genaro Pérez", la idea era construir una especie de continuidad y profundización de aquello iniciado en Buenos Aires a finales de los sesenta - a su vez réplica de lo iniciado en Francia y los Estados Unidos-, al combinar la aproximación erudita a la historieta con la idea de una comunidad de iguales en relación directa a sus lectores. Es decir, una comunidad legitimada popularmente.

Así, tradición e innovación parecían entrelazarse, operación permitida por las ventajas comparativas de la provincia: Córdoba era una capital histórica, con circuitos culturales propios y apoyo de capitales de la industria. Sin embargo, la diferencia estribaba en estar en mitad del país, lo que le permitía por un lado extenderse hacia el norte atlántico; y por otro al país profundo, a menudo ignorado por la capital portuaria.

De esta manera, la medianía geográfica cordobesa permitía la adaptación, desde una perspectiva local, de una historia escrita en las metrópolis del norte (París, Nueva York) y la capital federal (Buenos Aires). Córdoba se integraba a esa historia como una metrópoli por mérito propio. Esto, sin embargo, produjo algunas contradicciones hacia el interior de la Bienal como espacio de reconocimiento, además de los límites materiales y coyunturales que impidieron llevar el proyecto original de Salomón más allá de lo declarado por el director desde un principio.

Las bienales funcionaron con base en principios contradictorios: lo nacional y lo extranjero; tradicionalismo y cosmopolitismo; oficio y arte; imagen y palabra. Se legitimaba a la historieta y al humor gráfico desde su base popular, en una actividad cuya sede era un museo de arte clásico.

Al momento de reconstruir la historia universal del medio, se retomaban las fórmulas del norte (los antepasados europeos con los maestros estadounidenses como sucesores y fundadores modernos del lenguaje y del negocio). En 
cuanto a la tradición nacional, sin duda estaba basada mayormente en la producción de tirada nacional que tenía su origen en Buenos Aires.

Durante este periodo, las bienales parecieron no poder aprovechar del todo la oportunidad de escribir una historia de la historieta desde Córdoba. Esta limitación inicial — como admitía Salomón en 1974- incidió para que los intentos revisionistas se limitaran a readaptar el canon tal cual se había estado construyendo: no se fue más allá de incluir a Hortensia como aporte local a la genealogía originaria.

Esto también influyó en la construcción de un canon argentino, que si bien tenía sus orígenes en el siglo xIx y un impulso definitivo en los periódicos y revistas de principio del siglo $\mathrm{xx}$, seguía estando fuertemente atado a la idea de "Edad Dorada"; un periodo que iba desde finales de los años treinta hasta principios de los sesenta. Ese trecho había definido el carácter nacional y popular de las tiras y los personajes los cuales, por otra parte, estaban basados en buena parte en la cotidianidad porteña y en los estereotipos construidos desde el imaginario capitalino.

Para 1979, el internacionalismo cambiaba la ecuación de la Bienal: la inserción ya no era meramente discursiva, sino que se pasaba de la potencia al acto. Los invitados extranjeros — ecos de la experiencia del Di Tella- funcionaban no sólo como autores consagrados sino como representantes de las dos tradiciones más importantes del mundo occidental (Europa y Estados Unidos) que otorgaban legitimidad a Córdoba como epicentro de una tradición propia.

La internacionalización de algunos autores locales los posicionaba como parte de ese star system, lo que en retrospectiva parecía reivindicar la tradición argentina de la historieta y el humor. Visto así, se podía ser un trabajador de la industria del entretenimiento y a la vez un artista sin mayores conflictos. Sin embargo, este doble reconocimiento estaba en tensión con cómo los dibujantes se habían pensado tradicionalmente a sí mismos (trabajadores y no artistas); y muchos de ellos trabajaban for export, en general para Italia pero también para España, Inglaterra y en muy menor medida, los Estados Unidos. De hecho, muchas de esas obras no se conocerían en Argentina hasta años después de haber sido publicadas en el extranjero.

El "oficio" — como enfatizaban siempre las portadas de Di Lorenzi- estaba basado en una cierta idea de industria que arrastraba una crisis de más de una década, verificada en la caída de las ventas con los consecuentes cierres de revistas y editoriales. A esto se le sumaba un ambiente político represivo que atacaba de manera violenta la libertad de expresión. La añoranza de esa Épo- 
ca Dorada de alguna manera indicaba que aquellos volúmenes de producción y consumo no volverían.

Aquello que no podía ser sostenido desde lo material, era reificado simbólicamente en el espacio museístico y elevado al nivel de arte. La presencia de Berni servía de medida — algo hecho explícito en los textos y testimoniosa la condición artística de la historieta la cual, sin embargo, ganaba la pulseada por la popularidad. De esta manera, Berni aparecía como representante de la alta cultura que, al igual que los autores extranjeros, legitimaba la existencia y el valor de la Bienal como institución plebeya.

Paradójicamente, el precio a pagar por la artisticidad sería depender de la exportación de historietas, con su consecuente deshistorización, para abastecer de entretenimiento a los mercados europeos en plena expansión frente a la decadencia de la industria local, que pagaba en moneda depreciada. Para los dibujantes, pesaba más el aspecto asalariado, pero también la posibilidad de mayores cuotas de libertad de expresión y experimentación.

Después de 1979, la Bienal de Historieta y Humor Gráfico dejaría de realizarse hasta 1984. Para ese entonces el contexto político y editorial argentino sería muy diferente. Alberto Cognini había muerto un año antes y la posición de la Bienal frente al retorno de la democracia fue nítida y definida. Pero esa ya es otra historia. \&

N.B. Quisiéramos agradecer especialmente la ayuda y asistencia de Judith Gociol del Archivo de Historieta y Humor Gráfico Argentinos de la Biblioteca Nacional Mariano Moreno y a Laura Nallely Hernández Nieto, de la Universidad Nacional Autónoma de México. 